\title{
Początek pontyfikatu i I Pielgrzymka Jana Pawła II do Ojczyzny w świetle materiałów Komitetu Wojewódzkiego PZPR w Toruniu
}

Michał Białkowski*

\section{Wprowadzenie}

Podejmowane w ostatnich kilkunastu latach badania nad mechanizmami władzy w PRL obejmują również struktury PZPR, zakres i formy jej oddziaływania oraz miejsce $\mathrm{w}$ systemie politycznym ${ }^{1}$. Obraz, który się wyłania, wskazuje jednoznacznie, że partia była jednym z najważniejszych ośrodków decyzyjnych państwa komunistycznego ${ }^{2}$. W prak-

${ }^{*}$ Dr, historyk, politolog, regionalista; adiunkt w Katedrze Historii Dyplomacji na Wydziale Politologii i Studiów Międzynarodowych Uniwersytetu Mikołaja Kopernika w Toruniu. Prezes Klubu Inteligencji Katolickiej w Toruniu; sekretarz Porozumienia Klubów Inteligencji Katolickiej w Polsce.

${ }^{1}$ Zob. m.in. artykuły zawarte w publikacji: Władza w PRL. Ludzie i mechanizmy, red. K. Rokicki, R. Spałek, Warszawa 2011.

${ }^{2}$ Podstawowa literatura tego zagadnienia: Centrum władzy. Protokoły posiedzeń kierownictwa PZPR wybór z lat 1949-1970, oprac. A. Dudek, A. Kochański, K. Persak, Warszawa 2000; K. Persak, Struktura i sktad centralnych instancji decyzyjnych KC PZPR, [w:] Centrum władzy w Polsce 1948-1970, red A. Paczkowski, Warszawa 2003, s. 19-50; Ł. Kamiński, Przewodnia siła narodu, Biuletyn IPN, nr 5(2002), s. 7; J. Karpiński, Ustrój komunistyczny w Polsce, Warszawa 2005, s. 63-98; PZPR jako machina władzy, red. D. Stola i K. Persak, Warszawa 2012; R. Spałek, Komuniści przeciwko komunistom. Poszukiwanie wroga wewnętrznego $w$ kierownictwie partii komunistycznej w Polsce w latach 1948-1956, Warszawa-Poznań 2014; Elity komunistyczne w Polsce, red. M. Szumiło i M. Żukowski, Warszawa-Lublin 2015; Partia, państwo, spoleczeństwo, red. K. Rokicki, Warszawa 2016; A. Boboli, „Przewodnia siła stolicy”. Komitet Warszawski Polskiej Zjednoczonej Partii Robotniczej 1975- 
tyce politycznej Polski Ludowej granica pomiędzy interesami władzy państwowej (wyrażanymi poprzez działania instytucji oraz organów rządowych) a interesami aparatu partyjnego ulegała całkowitemu zamazaniu. Podobnie relacje państwo - Kościół katolicki zastępowane były kontaktami przedstawicieli aparatu partyjnego $\mathrm{z}$ hierarchami ${ }^{3}$. Udział PZPR w montażu systemu komunistycznego oraz zapewnienie mu względnej trwałości przez ponad cztery dekady możliwy był m.in. dzięki: 1) masowemu charakterowi ugrupowania ${ }^{4}$; 2) powstaniu zjawiska nomenklatury partyjnej ${ }^{5}$; 3 ) rozbudowanej, piramidalnej strukturze

1990, Warszawa 2016; PRL na pochylni (1975-1980), red. M. Bukała, D. Iwaneczko, Rzeszów 2017.

${ }^{3}$ Relacjom państwo-Kościół katolicki w okresie PRL poświęcone zostały zbiory dokumentów oraz monografie (wybór): P. Raina, Kościót katolicki a państwo w świetle dokumentów 1945-1989, t. 1: Lata 1945-1959, Poznań 1994; t. 2: Lata 1960-1974, Poznań 1995; t. 3: Lata 1975-1989, Poznań 1996; B. Fijałkowska, Partia wobec religii i Kościoła w PRL, t. 1: 1945-1955, Olsztyn 1999; t. 2, cz. 1: 1956-1963, cz. 2: 1964 1970, Olsztyn 2000-2001; A. Dudek, R. Gryz, Komuniści i Kościót w Polsce (19451989), Kraków 2003; J. Żaryn, Dzieje Kościoła katolickiego w Polsce (1944-1989), Warszawa 2003; Metody pracy operacyjnej aparatu bezpieczeństwa wobec Kościołów i zwiazków wyznaniowych 1945-1989. Dokumenty, wstęp, wybór dokumentów, redakcja A. Dziurok, Warszawa 2004; Kościót i Prymas Stefan Wyszyński 1956-1966, red. A. Dziurok i W. J. Wysocki, Katowice-Kraków 2007; B. Noszczak, Polityka państwa wobec Kościoła rzymskokatolickiego w Polsce w okresie internowania prymasa Stefana Wyszyńskiego 1953-1956, Warszawa 2008; A. Dziurok, Kruchtoizacja. Polityka władz partyjno-państwowych wobec Kościoła katolickiego w latach 1945-1956 w województwie ślaskim/katowickim, Katowice 2012; R. Łatka, Polityka władz PRL wobec kościoła katolickiego w województwie krakowskim w latach 1980-1989, Kraków 2016.

${ }^{4}$ W 1948 r. PZPR liczyła 1,460 mln członków, w 1950 r. - 1,240 mln, w 1960 r. $1,154 \mathrm{mln}$, w 1970 r. $-2,319 \mathrm{mln}$. Dynamiczny wzrost członków partii nastąpił jednak dopiero w dekadzie Edwarda Gierka - w 1974 r. liczyła ona 2,436 mln członków, w 1976 r. $-2,568 \mathrm{mln}$, w 1978 r. - 2,930 mln, a w 1980 r. - 3,149 mln. Zob. W. Góra, Polska Ludowa 1944-1984. Zarys dziejów politycznych, Lublin 1986, s. 465, 533-534, 573-574.

${ }^{5} \mathrm{Na}$ wszystkich szczeblach aparatu partyjnego doszło do jej rozbudowy przez podporządkowanie danej instancji partyjnej możliwie wielkiej liczby stanowisk i kompetencji. Obok komitetów wojewódzkich w prawo podejmowania decyzji kadrowych wyposażono też (jeszcze w latach pięćdziesiątych XX w.) komitety powiatowe, miejskie i dzielnicowe. O sprawach personalnych - i to wbrew wyraźnym zakazom władz zwierzchnich - próbowały jednak decydować również najniższe ogniwa partyjne: egzekutywy komitetów gminnych, komitetów zakładowych, a nawet podstawowych organizacji partyjnych (POP) - A. Dudek, PRL bez makijażu, Kraków 2008, s. 9-22; A. Pacz- 
organizacyjnej obejmującej Komitet Centralny (KC), komitety wojewódzkie $(\mathrm{KW})$, komitety miejskie (KM), komitety powiatowe (KP), komitety gminne $(\mathrm{KG})$ i komitety zakładowe $(\mathrm{KZ})^{6}$; 4) funkcjonowaniu wyspecjalizowanych jednostek (naukowo-badawczych, kontrolnych i medialnych) ${ }^{7}$.

Przedmiotem niniejszego artykułu jest ukazanie działań podejmowanych przez lokalny Komitet Wojewódzki PZPR w Toruniu w związku z wydarzeniami, jakie miały miejsce pomiędzy 16 października $1978 \mathrm{r}$. a 10 czerwca 1979 r. Przyjęcie perspektywy peryferyjnego Komitetu Wojewódzkiego - pozornie mało atrakcyjne - wydaje się w pełni uzasadnione i celowe. Pozwala bowiem na dostrzeżenie wielu zjawisk z poziomu struktur partyjnych średniego szczebla, niezaangażowanych decyzyjnie bezpośrednio w zachodzące wówczas wydarzenia. Co więcej, jest to obraz terenu dość specyficznego, znajdującego się poza programem podróży apostolskiej papieża do Polski w 1979 r. W pierwszej części przedstawione zostaną kierownictwo, struktury organizacyjne i zadania Komitetu Wojewódzkiego PZPR w Toruniu w latach 19751980. W drugiej - analiza materiałów partyjnych - reakcje aparatu na wybór kardynała Karola Wojtyły na Stolicę Piotrową, przygotowania do pielgrzymki papieskiej oraz sam jej przebieg.

\section{Komitet Wojewódzki PZPR w Toruniu w latach 1975-1980}

Komitet Wojewódzki PZPR w Toruniu powstał 1 czerwca 1975 r. z chwilą wejścia w życie reformy administracyjnej tworzącej 49 mikrowojewództw w miejsce 17 makrowojewództw. Na stanowisko I sekretarza Komitetu Wojewódzkiego PZPR powołany został Zygmunt Naj-

kowski, System nomenklatury, [w:] Centrum władzy w Polsce 1948-1970, s. 115-139; J. Staniszkis, Ontologia socjalizmu, Kraków-Nowy Sącz 2006, s. 124-134.

${ }^{6}$ Zob. Komitet Wojewódzki ogniwem władzy ludowej. Studium postaw aktywu partyjnego, oprac. pod kierunkiem M. Kuli na przykładzie zapisów posiedzeń KW PZPR w Gdańsku w latach 1949-1953, Warszawa 1997; PZPR w fabryce. Studium wrocławskiego „Pafawagu” w początku lat pięćdziesiatych, oprac. pod kierunkiem M. Kuli, Warszawa 2001.

${ }^{7}$ Zob. B. Cichocki, K. Jóźwiak, Najważniejsze sa kadry. Centralna Szkoła Partyjna PPR/PZPR, wstępem opatrzyli M. Kula i R. Turkowski, Warszawa 2006; K. Dąbek, PZPR. Retrospektywny portret wlasny, Warszawa 2006. 
dowski, który kierował partią w województwie toruńskim od 7 czerwca 1975 r. do 31 maja 1978 r. $^{8} \mathrm{~W}$ dniu 31 maja 1978 r. nastąpiła zmiana na stanowisku I sekretarza i funkcję tę objął Bolesław Kapitan (do 7 października 1980 r.). Był on zawodowym aparatczykiem, jeszcze w latach sześćdziesiątych XX w. pracował w Komitecie Wojewódzkim PZPR w Łodzi, a bezpośrednio przed objęciem fotela I sekretarza Komitetu Wojewódzkiego w Toruniu przewodniczył Głównemu Komitetowi Kultury Fizycznej i Turystyki ${ }^{9}$.

$\mathrm{W}$ drugiej połowie lat siedemdziesiątych $\mathrm{XX}$ w. struktura organizacyjna Komitetu Wojewódzkiego PZPR w Toruniu uległa charakterystycznej dla tamtej epoki rozbudowie. $W$ jego ramach funkcjonowały wówczas: Egzekutywa Komitetu Wojewódzkiego, Wojewódzka Komisja Kontroli Partyjnej, wydziały (Administracyjny, Ekonomiczny, Ideologii i Propagandy, Organizacyjny, Oświaty, Polityki Kadrowej i Społeczno-Prawny, Przemysłu i Handlu, Pracy Ideowo-Wychowawczej, Rolny i Gospodarki Żywnościowej), komisje, referaty, zespoły partyjne i komitety środowiskowe. Odrębną jednostką organizacyjną o znacz-

\footnotetext{
${ }^{8}$ Zygmunt Najdowski (ur. 25 kwietnia 1932 r., zm. 9 stycznia 1998 r.). Do PZPR wstapił w 1954 r. W 1957 r. został sekretarzem w Zarządzie Wojewódzkim ZMP w Bydgoszczy. W latach 1957-1959 I sekretarz Komitetu Uczelnianego PZPR UMK, a w latach 1964-1969 wiceprzewodniczący Zarządu Głównego ZMS w Warszawie. W 1975 r. był przewodniczącym Wojewódzkiej Rady Narodowej. I sekretarz KW PZPR w Toruniu (7 czerwca 1975 r. - 31 maja 1978 r.). Od grudnia 1975 r. do lipca 1981 r. członek KC PZPR. Minister kultury i sztuki (20 lipca 1978 r. - 8 października 1980 r.). Poseł na Sejm PRL VII kadencji (marzec 1976 r. - marzec 1980 r.). Odbył studia doktoranckie w WSNS przy KC PZPR (marzec 1977 r. - marzec 1980). Ponownie I sekretarz KW PZPR w Toruniu (7 października 1980 r. - 23 czerwca 1981 r.). Zob. Członkowie władz naczelnych oraz I sekretarze Komitetów Wojewódzkich PZPR 21.12.1948 -31.12.1982, oprac. W. Ciempiel, J. Jakubowski, J. Szczeblewski, Warszawa 1983, s. 329.

${ }^{9}$ Bolesław Kapitan (ur. 21 września 1932 r.). Działacz partyjny. Ukończył Wydział Historyczny Uniwersytetu Moskiewskiego. Przewodniczący Polskiego Komitetu Olimpijskiego oraz szef Głównego Komitetu Kultury Fizycznej i Turystyki (19731978 i 1986-1988). I sekretarz KW PZPR w Toruniu (31 maja 1978 r. - 7 października 1980 r.). W latach osiemdziesiątych XX w. przewodniczący Prezydium Stowarzyszenia Absolwentów Uczelni Radzieckich - organizacji grupującej wysokich funkcjonariuszy PZPR należących do tzw. „betonu partyjnego”. Poseł na sejm PRL VIII kadencji z okręgu wyborczego Toruń (marzec 1980 r. - marzec 1980 r.). W latach 1988-1990 konsul generalny w Leningradzie. Zob. Członkowie władz naczelnych oraz I sekretarze Komitetów Wojewódzkich PZPR, s. 329.
} 
nym stopniu samodzielności była Kancelaria I Sekretarza Komitetu Wojewódzkiego ${ }^{10}$. W tym czasie kierownicze stanowiska w Wydziale Organizacyjnym oraz w Kancelarii I Sekretarza Komitetu Wojewódzkiego piastowała Łucja Igielska ${ }^{11}$.

W pierwszych latach funkcjonowania struktur wojewódzkich liczba członków PZPR wynosiła: w grudniu 1976 r. $-48248^{12}$, w grudniu 1977 r. $-53701^{13}$. Jednak już latem 1980 r. zanotowano wyraźny spadek, a w maju 1981 r. szeregi partii stopniały do $51140^{14}$. Fakt ten miał niewątpliwie związek z nieudanymi próbami reform w PZPR oraz narodzinami „struktur poziomych”, szczególnie aktywnych właśnie w województwie toruńskim ${ }^{15}$.

\section{Analiza materiałów partyjnych}

Wybór polskiego kardynała - arcybiskupa metropolity krakowskiego Karola Wojtyły - na Stolicę Piotrową był bezprecedensowym wy-

\footnotetext{
${ }^{10} \mathrm{~W}$ dniu 3 października 1981 r. doszło do jednej z ostatnich zmian w strukturze organizacyjnej KW PZPR w Toruniu. Zmiany te wynikały na pewno z doświadczeń ponad sześciu lat funkcjonowania KW w Toruniu. Nie można jednak wykluczyć, że miały one także w sposób symboliczny zakończyć epokę gierkowską (1970-1980), którą charakteryzował biurokratyczny przerost kadr partyjnych. Wyodrębniono wówczas tylko sześć głównych wydziałów KW: Organizacyjny, Ideologiczny, Kancelaria Egzekutywy, Ekonomiczny, Rolny i Gospodarki Żywnościowej, Ogólny. Zob. Informator Wojewódzkiej Organizacji Partyjnej PZPR. Komitet Wojewódzki w Toruniu, nr 40/81, s. 11-15.

${ }^{11}$ Obecnie Łucja Igielska-Noch (ur. 2 sierpnia 1938 r.). Członek PZPR od 1958 r. Aktywna działaczka ruchu młodzieżowego - ZMP i ZMS od 1967 r. Przed nominacją na sekretarza KW PZPR w Toruniu była II sekretarzem KP PZPR w Wąbrzeźnie. Zastępca członka KC PZPR. Sekretarz ds. Organizacyjnych KW PZPR w Toruniu ( 1 czerwca 1975 r. - 5 listopada 1980 r.). Przewodnicząca Wojewódzkiego Społecznego Komitetu ORMO w Toruniu do 21 stycznia 1983 r. W 1981 r. odeszła z pracy w aparacie partyjnym. Zob. Archiwum Państwowe w Toruniu (dalej: APT), Zespół Komitetu Wojewódzkiego PZPR w Toruniu (dalej: KW PZPR w Toruniu), 48, k. 1; 58, k. 152; 411, k. 89, 96; Listy płac; Kierunki rozwoju województwa tematem narady aktywu partyjno-gospodarczego, Nowości z dnia 9 czerwca 1975 r., s. 1, 3.

${ }_{12}$ Biuletyn Informacyjny PZPR. Komitet Wojewódzki w Toruniu, nr 1/17: 1979, s. 64.

${ }^{13}$ Ibid., s. 64.

${ }^{14}$ Biuletyn Informacyjny PZPR. Komitet Wojewódzki w Toruniu, nr 18: 1981, s. 13.

${ }^{15}$ R. Bäcker, Struktury poziome w Toruniu 1980-1981, Warszawa 1990, s. 7-40.
} 
darzeniem w ponadtysiącletnich dziejach państwa polskiego. Dla społeczeństwa polskiego rozwijającego się w szczególnych, hermetycznych warunkach systemu totalitarnego inauguracja pontyfikatu PapieżaPolaka i Jego I Pielgrzymka do Ojczyzny przyniosły ze sobą nieznany do tej pory wybuch powszechnej radości, euforii oraz nadziei na przywrócenie swobód religijnych milionom katolików żyjących w kraju nad Wisłą ${ }^{16}$.

Reakcje społeczne, szczególnie te spontaniczne, nie mogły jednak pozostać poza sferą analizy, kontroli i obserwacji reżimu komunistycznego. Przyglądano się zatem wystąpieniom młodzieży akademickiej, inicjatywom laikatu katolickiego, wypowiedziom duchownych. Ze szczególnym zrozumieniem przyjmowano spostrzeżenia, uwagi i zaniepokojenie ,postępowej siły narodu” - aktywu partyjnego. Do trwałych skutków decyzji Kolegium Kardynalskiego z 16 października 1978 r. w wymiarze polityki wyznaniowej władz PRL należy zaliczyć więc pełną mobilizację wszystkich struktur aparatu represji. W znaczeniu szerszym - sensu largo - obejmowały one nie tylko sam aparat bezpieczeństwa (utożsamiany ze wszystkimi jednostkami organizacyjnymi podległymi resortowi MSW), ale także specjalistyczne agendy aparatu rządowego (Urząd do Spraw Wyznań oraz Główny Urząd Kontroli Prasy, Publikacji i Widowisk), organy administracji terenowej (wojewódzkie, powiatowe, miejskie i gminne rady narodowe) oraz struktury PZPR.

Wśród 3049 jednostek aktowych zespołu Komitetu Wojewódzkiego PZPR w Toruniu (lata 1975-1990), znajdującego się w zasobach Archiwum Państwowego w Toruniu, ważną część zajmują akta Kancelarii I Sekretarza Komitetu Wojewódzkiego. W codziennych raportach

\footnotetext{
${ }^{16}$ T. Szulc, Papiez Jan Pawet II. Biografia, przeł. Z. Uhrynowska-Hanasz, M. Wroczyński, Warszawa 1999, s. 264-291; J. Moskwa, Jan Pawet II. Autorytety, Warszawa 2005, s. 56-61; P. Skibiński, Pielgrzymki Jana Pawła II do Ojczyzny (1979-2002) i ich kontekst historyczny, Teologia Polityczna, 3/2005-2006, s. 166-170; S. Dziwisz, G. F. Svidercoschi, Świadectwo, Poznań 2007, s. 62-63; Najnowsza historia Kościoła. Katolicy i Kościoły chrześcijańskie w czasie pontyfikatu Jana Pawta II (1978-2005), red. E. Guerriero, M. Impagliazzo, przeł. J. Partyka, Kraków 2008; s. 16-37; P. Zuchniewicz, Jan Pawet II. „Będę szedt naprzód”, Kraków 2009; s. 13-32, 67-117; A. Riccardi, Jan Pawet II. Biografia, tłum. K. Stopa, Częstochowa 2014, s. 316-317.
} 
przesyłanych w formie teleksów bezpośrednio do Sektora Informacji Wydziału Organizacyjnego Komitetu Centralnego PZPR odnajdziemy obraz życia politycznego, społecznego i gospodarczego województwa toruńskiego u schyłku dekady Edwarda Gierka. Spośród teleksów zapewne dla celów praktycznych najprawdopodobniej w pierwszej połowie lat osiemdziesiątych XX w. wyodrębniono materiały chronologicznie i tematycznie związane z wyborem Jana Pawła II w październiku 1978 r. oraz Jego I Pielgrzymką do Ojczyzny w czerwcu 1979 r. Powstały wówczas dwie odrębne jednostki aktowe (oznaczone sygn. 362 i 365). Materiały te oraz inne powiązane tematycznie teleksy z okresu od zimy 1978/1979 r. do lata 1979 r. (oznaczone sygn. 363 i 364) są podstawowym materiałem źródłowym służącym do dalszej analizy. Warto dodać, że informacje zawarte w teksach odnoszą się zasadniczo do działań organizacyjnych podejmowanych przez: Kurię Biskupią Chełmińską ${ }^{17}$, Kurię Metropolitalną Gnieźnieńską ${ }^{18}$ oraz Konferencję Episkopatu Polski.

\section{A. Wybór kardynała Karola Wojtyły na papieża (październik 1978 r.)}

Mieczysław F. Rakowski - wówczas redaktor naczelny „Polityki” i członek Komitetu Centralnego PZPR - we wspomnieniach z jesieni 1978 r., pod datą 16 października zanotował:

Po południu wyjazd autokarem do Olsztyna na drugie Forum PRL-RFN. Już w drodze dochodzi do nas wiadomość o wyborze kardynała Wojtyły na papieża. Zrazu nie możemy w to uwierzyć, chociaż muszę przyznać, że czytając kiedyś w „BS-ie”, że już na poprzednim konklawe miało szanse dwóch kardynałów nie-Włochów (Argentyńczyk i Polak), pomyślałem przez moment, że kto wie, czy Wojtyła nie zostanie papieżem, ale po chwili odrzuciłem tę myśl. Nowy papież przybrał imię Jan Paweł II.

W hotelu, w którym zostaliśmy zakwaterowani, panuje olbrzymie podniecenie. Po godzinie zjawili się Niemcy, również bardzo poruszeni wiadomo-

\footnotetext{
${ }^{17}$ Podlegało jej terytorialnie województwo toruńskie bez lewobrzeżnej części Torunia i graniczących z nią gmin.

${ }^{18}$ Podlegały jej terytorialnie lewobrzeżna część Torunia (Kluczyki, Podgórz, Stawki, Rudak, Czerniewice) i okoliczne gminy.
} 
ścią, jaką usłyszeli. Jest to rzeczywiście wydarzenie o ogromnym znaczeniu. $\mathrm{Na}$ gorąco je komentuję. Wybór Wojtyły niesłychanie wzmacnia katolicyzm w Polsce, osłabia pozycję Polski w bloku socjalistycznym (już słyszę, jak w Moskwie mówią: no, teraz Polacy mają w Waszyngtonie Brzezińskiego, a w Rzymie Wojtyłę), ale podnosi się nasza pozycja w świecie. Dziennikarze zachodnioniemieccy, którzy przybyli do Olsztyna, po godzinie zwijają manatki i wyruszają do Warszawy. Wyobrażam sobie, co się będzie działo w najbliższych dniach w prasie światowej, a także w kraju ${ }^{19}$.

Natomiast dwa dni później, 18 października 1978 r., pisał:

Wczorajsze obrady Forum zaczęły się od złożenia nam przez Niemców gratulacji z okazji wyboru Wojtyły na papieża. $Z$ naszej strony nikt nie podziękował. Widocznie Piątkowski nie otrzymał w tej sprawie instrukcji z Warszawy. Wobec tego przed wygłoszeniem referatu podziękowałem Niemcom za gratulacje i krótko określiłem znaczenie dla Polski wyboru Wojtyły na papieża. Nadal oczywiście głównym tematem rozmów jest to wydarzenie. Ja reprezentuję pogląd, że 16 października 1978 roku otwiera nową kartę w powojennej historii Polski. Nie ulega dla mnie wątpliwości, że wybór Wojtyły wzmocni to, co określamy dumą narodową Polaków. Może ona objawić się również w ten sposób, że Polacy dojdą do wniosku, iż mogą być bardziej niezależni zarówno w stosunku do swoich komunistów, jak i wobec Związku Radzieckiego $^{20}$.

Również dzień po inauguracji pontyfikatu umysł redaktora naczelnego „Polityki” wciąż zaprzątała osoba nowego papieża:

Wszyscy moi koledzy w KC nadal komentują wybór Wojtyły, zastanawiając się nad konsekwencjami tego wydarzenia. Panuje opinia, że jest to oczywiście cios dla komunistów. Dużo komentarzy wzbudza także zachowanie się nowego papieża. Jest bardzo elokwentny, bezpośredni, mówi w sześciu językach. Słowem - człowiek wielkiego formatu. Na pewno przyćmi Gierka i nie wykluczam, że ten, w skrytości ducha, boleje nad tym. Nie on będzie od tej pory pierwszym Polakiem.

[...] W mojej redakcji wybór Wojtyły wywołał również sporo emocji, a nawet euforię. Kilku kolegów zachowywało się tak, jakby już jutro miało dojść do zmiany rządów komunistycznych w Polsce ${ }^{21}$.

\footnotetext{
${ }^{19}$ M. F. Rakowski, Dzienniki polityczne 1976-1978, t. 6, Warszawa 2002, s. 418.

${ }^{20}$ Ibid., s. 418.

${ }^{21}$ Ibid., s. 419.
} 
Trudno nie oprzeć się wrażeniu, że wybór Jana Pawła II był dla elit partyjnych wielkim zaskoczeniem, na które były kompletnie nieprzygotowane. To zadziwienie na pewno w pierwszej chwili paraliżowało, następnie wywoływało uczucie wielkiej wewnętrznej radości (którą można było tylko okazywać publicznie wyłącznie w formie dumy narodowej), a ostatecznie przynosiło panikę, przerażenie i strach. Należy przypuszczać, że panika, przerażenie i strach niosły ze sobą motywację do dalszych, efektywnych działań podejmowanych przez organy najwyższych władz PRL (Radę Państwa, rząd oraz KC PZPR). Po fazie załamania przyszła chwila refleksji oraz chłodnej, rzeczowej oceny sytuacji, która dość szybko nasunęła plan najpilniejszych przedsięwzięć. Wkrótce przywróciła stan pełnej kontroli aparatu represji nad społeczeństwem znajdującym się wciąż w fazie zachwytu ${ }^{22}$.

Pierwsze polecenia Komitetu Centralnego PZPR dotyczące przekazania zwięzłych informacji odnośnie do sytuacji w województwie toruńskim i reakcji społecznych na wybór Jana Pawła II dotarły do Komitetu Wojewódzkiego PZPR w Toruniu teleksem w dniu 17 października 1978 r. o godz. $8.51^{23}$. Jeszcze tego samego dnia sporządzone dwie odpowiedzi: pierwsza najprawdopodobniej została przekazana około godz. 9.30. Zwrócono w niej uwagę, iż wybór Polaka na papieża jest powszechnym zaskoczeniem, spodziewano się bowiem ponownego wyboru przedstawiciela Włoch lub innej narodowości ${ }^{24}$.

Druga - szersza analiza - sporządzona została jeszcze tego samego dnia w godzinach popołudniowych. Pisano w niej:

Informujemy, że wybór kardynała Wojtyły na Papieża wywołał duże poruszenie wśród kleru i aktywu katolickiego.

Kler zakonny twierdzi, że wybór ten jest ukłonem dla Polski i naszego Kościoła. Należy być dumnym z faktu uznania polskiego Kościoła w Kolegium Kardynalskim tym bardziej, iż powszechnie uważa się naszych dostojników kościelnych za konserwatystów.

\footnotetext{
${ }^{22}$ Podobne spostrzeżenia co do samego wyboru Karola Wojtyły na papieża oraz skutków tego faktu znajdujemy w książce Polska Ludowa. Modzelewski, Werblan. Rozmawia Robert Walenciak, Warszawa 2017.

${ }^{23}$ APT, KW PZPR w Toruniu, Kancelaria I Sekretarza, 362, teleksy dotyczące pontyfikatu papieża Jana Pawła II, k. 1, teleks nr 258 z KC PZPR w Warszawie wysłany w dniu 17 października 1978 r. o godz. 8.51.

${ }^{24}$ Ibid., k. 2, teleks nr 214/1/78 z dnia 17 października 1978 r.
} 
Wśród kleru mówi się, że Papież Wojtyła pomimo stosunkowo młodego wieku dał się poznać jako zdolny fillozof i teolog, cieszył się szczególną sympatią krakowskiego środowiska studenckiego. Przypuszcza się w tym środowisku, że nasili się obecnie ilość pielgrzymek do Częstochowy i Krakowa z Zachodu, a wybór skomplikuje sytuację w polskim Episkopacie. Mówi się przy tym, że w najbardziej kłopotliwej sytuacji znalazł się kardynał Wyszyński, który będzie musiał złożyć pokłon swojemu dotychczasowemu podwładnemu.

Sporo księży twierdzi, że wybór Papieża spowoduje pogorszenie stosunków państwa z Kościołem w Polsce.

W środowisku aktywu duszpasterstwa akademickiego występują opinie, że Wojtyła był uważany za biskupa „wojującego” krytycznie nastawionego do Prymasa Wyszyńskiego i normalizacji stosunków państwa z Kościołem. Liczy się, że z wyboru tego wynikną bezpośrednie korzyści dla Kościoła w Polsce, a dalsze stosunki państwa $z$ Kościołem ulegną napięciu.

Przewiduje się, że przyjazd Papieża do Polski nastąpi dopiero w 1982 r. na uroczystości religijne w Częstochowie ${ }^{25}$.

$\mathrm{W}$ informacji tej podano również kilka szczegółowych informacji odnoszących się do reakcji świeckich na wybór Jana Pawła II. Stwierdzono m.in., że członkowie Klubu Inteligencji Katolickiej w Toruniu podczas wieczornego spotkania wiadomość o wyborze kardynała Karola Wojtyły na papieża przyjęli owacyjnie i odśpiewali pieśń „Boże coś Polskę".

Przekazano także wiadomości pochodzące rzekomo ze środowiska akademickiego. Stwierdzono, że wśród pracowników naukowych UMK Karol Wojtyła postrzegany jest jako nieprzejednany przeciwnik socjalizmu. Nowy papież miał być również - według tych informacji - autorem nieopublikowanej pracy naukowej poświęconej taktyce działania Kościoła wobec komunistów, która miała znajdować się do użytku wewnętrznego w Katolickim Uniwersytecie Lubelskim ${ }^{26}$.

Kolejne relacje przesłane już w dniu 18 października 1978 r. były coraz obszerniejsze. Zwrócono uwagę, iż papież mimo stosunkowo młodego wieku ma bogate doświadczenie w pracy duszpasterskiej ${ }^{27}$. Po-

\footnotetext{
${ }^{25}$ Ibid., k. 5, teleks nr 215/1/78 z dnia 17 października 1978 r.

${ }^{26}$ Ibid., k. 6, teleks nr 215/1/78 z dnia 17 października 1978 r.

${ }^{27}$ Ibid., k. 7, teleks nr 215/1/78 z dnia 18 października $1978 \mathrm{r}$.
} 
nadto przedstawiono opinie środowisk naukowych dotyczące jego walorów intelektualnych:

W środowiskach naukowych wysoko ocenia się jego inteligencję, talent dyplomatyczny, znajomość kilku języków, jego udział w pracach soborowych komisji w Watykanie ${ }^{28}$ oraz co należy do rzadkości uznanie i aprobatę francuskiej, niemieckiej i amerykańskiej hierarchii Kościoła rzymskokatolickiego.

Uważa się, że będzie on mądrze i rozsądnie kontynuował obecną linię polityki w Watykanie. Tym bardziej, że jako pierwszy od 455 lat nie Włoch, a jedyny w historii Polak musi liczyć się z bardzo wnikliwą i nie bardzo życzliwą obserwacją ze strony dygnitarzy kościelnych, a nawet całych społeczności.

Wśród wierzących studentów UMK stwierdzono komentarze, że wreszcie Polska będzie znowu krajem czysto religijnym oraz z szacunkiem przedstawia się osobowość Wojtyły, jego serdeczność, przystępność i bezpośredniość w kontaktach międzyludzkich. Ton tym dyskusjom nadają OO. Jezuici z Torunia $^{29}$.

[...] Wczorajsza relacja TV z nabożeństwa w Kaplicy Sykstyńskiej znalazła szerokie uznanie i aprobatę społeczną wśród wiernych, a mówi się przy tym o dumie narodowej z faktu wyboru Kardynała Wojtyły na Papieża.

Bardzo pozytywnie przyjęte zostało przez społeczeństwo przekazanie przez władze centralne PRL papieżowi depeszy jako synowi polskiego narodu budującego socjalizm w związku z wyborem go na ten urząd. W opinii wielu wypowiadających się stanowisko to jest uznawane jako dalekosiężne ${ }^{30}$.

Zauważono również, że księża należący do Zrzeszenia Katolików „Caritas” obawiają się o przyszłość tej organizacji, gdyż, jak podkre-

\footnotetext{
${ }^{28}$ Karol Wojtyła - jako arcybiskup krakowski - w okresie obrad Soboru Watykańskiego II uczestniczył w pracach podkomisji przygotowującej część schematu XIII (przyszłej Konstytucji duszpasterskiej o Kościele w świecie współczesnym „Gaudium et spes”). Istotny był również jego głos podczas debaty nad Deklaracją o wolności religijnej „Dignitatis humanae”. Natomiast przykładem osobistego udziału kardynała Wojtyły w recepcji nauczania soborowego w Polsce była praca: U podstaw odnowy. Studium o realizacji Vaticanum II, wyd. 1, Kraków 1972. Zob. K. Wojtyła, Udziat biskupów polskich w Soborze Watykańskim II, Wiadomości Archidiecezjalne Warszawskie, 61(1971), nr 5, s. 40-46; R. Skrzypczak, Karol Wojtyła na Soborze Watykańskim II. Zbiór wystapień, Warszawa 2011; M. Białkowski, Wokót Soboru Watykańskiego II. Studia i szkice, Toruń 2016, s. 70-71.

${ }^{29}$ APT, KW PZPR w Toruniu, Kancelaria I Sekretarza, 362, teleksy dotyczace pontyfikatu papieża Jana Pawła II, k. 7, teleks nr 215/1/78 z dnia 18 października 1978 r.

${ }^{30}$ Ibid., k. 8, teleks nr 218/1/78 z dnia 18 października 1978 r.
} 
ślają, kardynał Karol Wojtyła był jednym z najbardziej zaangażowanych w jej likwidację.

Ponadto informowano, że w dniu 16 października 1978 r. administratorzy parafii w województwie zarządzili 15 -minutowe bicie w dzwony kościelne. Natomiast w dniu następnym - 17 października - w kościołach toruńskich odbywały się msze św. dziękczynne z uroczystym odśpiewaniem „Te Deum”. Jednocześnie podkreślono, że pozostałe parafie, szczególnie wiejskie, czekają na instrukcje z kurii biskupich. Nieprzypadkowo także w dniu 17 października 1978 r. do wojewody toruńskiego wpłynęła petycja o wydanie pozwolenia na budowę kościoła w dzielnicy Rubinkowo podpisana przez 12 mieszkańców tego osiedla ${ }^{31}$.

Kolejny teleks pochodzi już z 23 października 1978 r. Przesłany został więc tuż po inauguracji pontyfikatu, która odbyła się 22 października. W relacji zawarto ogólne informacje dotyczące przebiegu uroczystości na placu św. Piotra. W sposób szczególny zwrócono uwagę na pozytywny wydźwięk transmisji w radiu i w telewizji:

W pierwszych komentarzach i opiniach podkreśla się zadowolenie wśród wiernych, że po raz pierwszy dzięki TV mogli obejrzeć przebieg pontyfikatu. Mówi się przy tym, że umożliwienie przeprowadzenia relacji radiowotelewizyjnej z uroczystości świadczy o realizowaniu w praktyce zasad Konstytucji i pełnej tolerancji wobec wyznań religijnych.

Podkreśla się $\mathrm{z}$ zadowoleniem udział $\mathrm{w}$ uroczystościach delegacji i misji specjalnych z ponad 100 krajów, w tym naszej delegacji na czele z Przewodniczącym Rady Państwa PRL tow. Henrykiem Jabłońskim jako wyraz uznania, że Papieżem został Polak ${ }^{32}$.

W sposób charakterystyczny dla słownictwa propagandy partyjnej odniesiono się również do udziału we mszy św. pielgrzymów z Polski:

$\mathrm{W}$ wielu wypowiedziach podkreśla się fakt udziału w uroczystościach pielgrzymów z Polski, którzy flagami narodowymi i transparentami manifestowali owacyjnie swój udział w uroczystościach, wskazując aprobatę dla przebiegu samych uroczystości, jak i osoby Papieża ${ }^{33}$.

Nie sprecyzowano jednak informacji o liczbie pielgrzymów pochodzących z Torunia i województwa, mimo że były to pojedyncze przy-

${ }^{31}$ Ibid., k. 9, teleks nr 218/1/78 z dnia 18 października 1978 r.

${ }^{32}$ Ibid., k. 11, teleks nr 221/1/78 z dnia 23 października 1978 r.

${ }^{33}$ Ibid., k. 12, teleks nr 221/1/78 z dnia 23 października 1978 r. 
padki. Do grona tego należał m.in. prezes toruńskiego KIK-u Jerzy Matyjek $^{34}$. Brak szczegółowych danych dotyczących środowisk laikatu katolickiego, których reprezentanci uzyskali zgodę na wyjazd do Rzymu, tłumaczyć należy raczej celowym pominięciem tych informacji. Przypuszczalnie wyczerpujące sprawozdania napływały do Komitetu Centralnego PZPR z Ministerstwa Spraw Wewnętrznych i z Urzędu do Spraw Wyznań, gdyż tam znajdowały się ośrodki decyzyjne kompetentne do wydawania zezwoleń na wylot do Rzymu na inaugurację pontyfikatu.

\section{B. Okres przygotowań do pielgrzymki papieskiej (marzec - maj 1979 r.)}

Wstępne, zakulisowe rozmowy dyplomatyczne w sprawie przyjazdu papieża do Polski prowadzone były już od grudnia 1978 r. ${ }^{35}$ Prośba Wydziału Organizacyjnego Komitetu Centralnego PZPR o zebranie informacji na temat reakcji społecznych związanych z zapowiedzią podróży Jana Pawła II do Ojczyzny skierowana została do Komitetu Wojewódzkiego PZPR 2 marca 1979 r. ${ }^{36}$ Cztery dni później z Torunia przesłano enigmatyczną odpowiedź, która w swej treści jest właściwie powtórzeniem komunikatu Polskiej Agencji Prasowej. Inaczej nie sposób bowiem interpretować następujących zdan:

Szczególne zadowolenie i uznanie dla władz partyjnych i państwowych za wyrażenie zgody na przyjazd papieża do Polski panuje w środowiskach religijnych. Mówi się, że świadczy to o wysokiej kulturze i mądrości władz, o przestrzeganiu zasad Konstytucji PRL.

\footnotetext{
${ }^{34}$ M. Białkowski, Oaza na Mostowej. Klub Inteligencji Katolickiej w Toruniu (1957-2007), Toruń 2008, s. 137.

${ }^{35}$ Początkowo władze partyjno-państwowe targowały się o termin przyjazdu papieża do Polski. Nie chciano zgodzić się na dzień 8 maja 1979 r., kiedy to w Krakowie od dawna planowano uroczyste obchody 900. rocznicy męczeńskiej śmierci biskupa Stanisława ze Szczepanowa, patrona Polski. Członek Biura Politycznego KC PZPR Stanisław Kania sugerował, aby papież przyjechał do kraju dopiero w 1982 r. Ostatecznie jednak decydenci ulegli perswazji Stolicy Apostolskiej, choć sam termin został przesunięty o miesiąc. Zob. Wizyta Jana Pawła II w Polsce 1979. Dokumenty KC i MSW, wstep i oprac. A. Friszke i M. Zaremba, Warszawa 2005, s. 35.

${ }^{36}$ APT, KW PZPR w Toruniu, Kancelaria I Sekretarza, 363, teleksy KW - KC styczeń - marzec 1979 r., k. 190, teleks z 6 marca 1979 r.
} 
W wielu innych środowiskach przyjęto ten fakt z pewną rezerwą, ale i powagą.

Twierdzi się, że wizyta papieża pozytywnie wpłynie na dalsze umocnienie pozycji Polski w świecie. Wyraża się jednak obawy, że papież i władze polskiego Kościoła mogą wywierać duży nacisk na rząd w kierunku rozwoju budownictwa sakralnego, nauczania religii, wprowadzania symboliki religijnej do niektórych instytucji i szpitali. Przypuszcza się, że papieża będą przyjmowały też czynniki partyjne i państwowe - włącznie z tow. E. Gierkiem ${ }^{37}$.

Realizując wytyczne Biura Politycznego Komitetu Centralnego co do przeprowadzenia rozmów z proboszczami i administratorami parafii, w teleksie wysłanym 24 maja 1979 r. podkreślono, że:

Na dzień 23 maja 1979 r., na stan 156 proboszczów, przeprowadzono 93 rozmowy. Zakończenie ich nastąpi 28 maja br. $Z$ wypowiedzi rozmówców wynika, że ze względu na dużą odległość i trudności komunikacyjne nie będą organizowane zbiorowe wyjazdy do Gniezna.

Niemniej Kuria Chełmińska, która koordynuje całością spraw związanych z przyjazdem papieża, złożyła zapotrzebowanie na 20 autobusów dla pielgrzymów zbiorowych ${ }^{38}$.

Wspomniane spotkania miały charakter sondażowy, ale ich prawdziwym celem było zniechęcenie administratorów parafii do organizacji masowych wyjazdów na spotkania z papieżem. Jednocześnie oceniano, że różnymi środkami lokomocji (PKP, PKS i samochody prywatne) w dniu 3 czerwca 1979 r. na mszę św. sprawowaną przez papieża na lotnisku w Gębarzewie pod Gnieznem wyjedzie z Torunia i okolic około 8-10 tysięcy wiernych. Zwrócono także uwagę, że w niedzielę 20 maja - w dużych parafiach miejskich odczytany został apel Komitetu Organizacyjnego Przyjazdu Papieża do Gniezna. Jego autor, sufragan gnieźnieński biskup Jan Michalski ${ }^{39}$, zachęcał do masowego

\footnotetext{
${ }^{37}$ Ibid.

${ }^{38}$ Ibid., 364, teleksy KW - KC marzec - czerwiec 1979 r., k. 132, teleks z 24 maja $1979 \mathrm{r}$.

${ }^{39}$ Biskup Jan Michalski (ur. 6 lutego 1914 r., zm. 23 sierpnia 1989 r.). Biskup sufragan gnieźnieński. W 1939 r. przyjął święcenia kapłańskie. Po święceniach wikariusz w Bydgoszczy i Nakle. Ukrywając się w okresie okupacji odbył studia konspiracyjne. Kapelan Armii Krajowej i uczestnik powstania warszawskiego. Po zakończeniu wojny i studiach w Lublinie profesor seminarium duchownego w Gnieźnie, kanonik i wikariusz generalny gnieźnieński. W dniu 6 grudnia 1975 r. mianowany biskupem tytularnym Vagal i sufraganem gnieźnieńskim. Sakrę biskupią przyjął 21 grudnia 1975 r.
} 
udziału w powitaniu papieża, ponieważ lotnisko mogło pomieścić nawet 3 miliony osób ${ }^{40}$.

W dniu 26 maja 1979 r. pisano:

Zwiększone zainteresowanie notujemy w środowisku studenckim Uniwersytetu Mikołaja Kopernika. Na uczelni pojawiły się plakaty informujące o imprezach zorganizowanych na cześć przyjeżdżającego papieża. W klubie „Życie i Myśl” (PAX) w Toruniu odbędzie się 29.05.1979 r. o godz. 20-tej spotkanie. Duszpasterze akademiccy - Redemptoryści organizują wyjazd 30osobowej grupy swojego aktywu do Warszawy w dniu 3.06.1979 r.

Wśród księży panuje zaniepokojenie, że transmisje z pobytu papieża będą niepełne i nie będzie np. relacji z Gniezna. Kuria Chełmińska otrzymała 63 przepustki na samochody osobowe, po jednej na dekanat. Otrzymała także drugi komunikat w sprawie przyjazdu papieża.

Gnieźnieński Komitet Organizacyjny Przyjazdu Papieża wydał apel o dekorowaniu miast i wsi elementami „religijnymi, papieskimi i narodowymi”.

Komitet ostrzega przed fałszywymi przepustkami, które już pojawiły się w obiegu, poinformował także, że z miejsc parkowania do miejsca uroczystości powitania papieża kursować będą specjalne autobusy dowożące wiernych. Komitet apeluje, by „porzucić lęk i obawy” przed trudnościami na miejscu ${ }^{41}$.

28 maja przekazano Komitetowi Centralnemu PZPR kolejną porcję danych. Sprecyzowano, iż z terenu województwa toruńskiego na mszę św. w Gębarzewie wyjedzie około 1000 osób 20 autokarami do Gniezna oraz 200 studentów pociągiem do Warszawy w dniu 3 czerwca. Ponadto szacowano, że do Gniezna wyjedzie około 1000 samochodów prywatnych, które mogą przewieźć 5000 osób. Łącznie razem z indywidualnymi wyjazdami pociągami liczono się z wyjazdem 8000 wiernych $^{42}$.

Szczególne zaniepokojenie władz partyjnych wzbudzała aktywność toruńskiego Klubu Inteligencji Katolickiej. Główna część teleksu z 29 maja 1979 r. poświęcona była sprawie tego właśnie stowarzyszenia.

z rąk kardynała Stefana Wyszyńskiego. Dziekan kapituły prymasowskiej. Zob. K. R. Prokop, Biskupi Kościoła katolickiego w III Rzeczpospolitej. Leksykon biograficzny, Kraków 1998, s. 94-95; P. Nitecki, Biskupi Kościoła w Polsce w latach 965-1999. Stownik biograficzny, Warszawa 2000, s. 33.

${ }^{40}$ APT, KW PZPR w Toruniu, Kancelaria I Sekretarza, 364, teleksy KW - KC marzec - czerwiec 1979 r., k. 132, teleks z 24 maja 1979 r.

${ }^{41}$ Ibid., k. 138, teleks nr 130/I/79 z 26 maja 1979 r.

42 Ibid., k. 141, teleks nr 131/I/79 z 28 maja 1979 r. 
Klub skierował bowiem oficjalną prośbę do Prezydenta Miasta Torunia o wyrażenie zgody na wywieszenie na siedzibie organizacji, przy ulicy Mostowej 10, transparentu z hasłem: „Klub Inteligencji Katolickiej modli się z Ojcem Świętym"43.

Ponadto Zarząd Klubu Inteligencji Katolickiej w Toruniu usilnie zabiegał o dodatkowy autokar na wyjazd swoich członków do Gniezna. $\mathrm{Z}$ nieskrywaną dumą i satysfakcją tow. Łucja Igielska meldowała do Warszawy, że w obu kwestiach wydano oczywiście odmowne decyzje. Jednak mimo czynionych przeszkód ostatecznie grupa ponad czterdziestu działaczy i członków toruńskiego KIK-u uczestniczyła w spotkaniu liturgicznym z Ojcem św. w Gębarzewie koło Gniezna 3 czerwca 1979 r. Wyjazdy miały charakter indywidualny, członkowie Klubu dojechali do Gniezna-Gębarzewa autobusami zorganizowanymi przez parafie, koleją lub własnym transportem. Również w tym samym dniu we mszy św. na Wzgórzu św. Wojciecha w Gnieźnie wzięli udział: prof. Karol Górski (założyciel i pierwszy prezes KIK-u), Barbara Matyjek (członek Zarządu KIK-u), Jerzy Matyjek i Krystyna Podlaszewska (skarbnik KIK-u ${ }^{44}$. Dzień później informowano:

Szerokie zainteresowanie wzbudziło spotkanie Kardynała Stefana Wyszyńskiego z I Sekretarzem KC PZPR Towarzyszem Edwardem Gierkiem. Spotkanie to zostało bardzo pozytywnie odebrane przez ogół społeczeństwa.

Wśród aktywu rodzi się zaniepokojenie, że ostatnie kontakty z Episkopatem i Watykanem, jak również sama wizyta Papieża mogą doprowadzić do wzrostu i zwiększenia aktywności wiernych.

W dalszym ciągu obserwujemy zainteresowanie transmisją TV z pobytu papieża. Zainteresowanie to podniecone jest przez samych księży. Notowane są wypowiedzi, szczególnie na terenie wiejskim, że w Polsce większość społeczeństwa jest wierząca i dwie transmisje to za mało. Powinny być jeszcze z Jasnej Góry i z Krakowa ${ }^{45}$.

[...] Od dnia wczorajszego wzmaga się dekoracja obiektów sakralnych i kościelnych flagami papieskimi i niebieskimi oraz portretami papieża ${ }^{46}$.

\footnotetext{
${ }^{43}$ Ibid., k. 144, teleks nr 131/I/79 z 29 maja 1979 r.

${ }^{44}$ M. Białkowski, Oaza na Mostowej. Klub Inteligencji Katolickiej w Toruniu (19572007), s. 139

${ }^{45}$ APT, KW PZPR w Toruniu, Kancelaria I Sekretarza, 364, teleksy KW - KC marzec - czerwiec 1979 r., k. 145, teleks nr 132/I/79 z 30 maja 1979 r.

${ }^{46}$ Ibid.
} 
Przy czym już samo użycie obraźliwych zwrotów: „podniecone jest” oraz „wzmaga się” odzwierciedla pejoratywny stosunek aparatu partyjnego do zwyczajnych zachowań osób wierzących.

\section{I Pielgrzymka Papieża-Polaka do Ojczyzny (czerwiec 1979 r.)}

Od końca maja 1979 r. informacje przekazywane do Komitetu Centralnego PZPR zawierają bardziej szczegółowe dane na temat przygotowań duchowieństwa i wiernych do wizyty papieża. W tym czasie, w celu zapewnienia sprawnego przesyłu informacji, na linii Komitet Centralny - Komitet Wojewódzki uruchomiono nadzwyczajne procedury. Zdecydowano, iż w okresie od 1 do 11 czerwca 1979 r. w Wydziale Organizacyjnym Komitetu Centralnego PZPR oraz we wszystkich komitetach wojewódzkich obowiązywać będą całodobowe dyżury pracowników politycznych. Ponadto wszystkie komitety wojewódzkie zostały zobowiązane do codziennego przesyłania do godz. 10.00 informacji przy użyciu dalekopisu. $Z$ województw, w których aktualnie przebywał papież, meldunki miały być przesyłane dwukrotnie - przed godz. 7.00 i po 20.00 . Wezwano także władze terenowe do przeprowadzenia rozmów z administratorami parafii oraz przedstawicielami środowisk laikatu katolickiego ${ }^{47}$.

Pierwsza Pielgrzymka Papieża-Polaka do Ojczyzny trwała dziewięć $\mathrm{dni}^{48}$. Papież odwiedził wówczas: Warszawę (2 czerwca 1979 r.), Gniezno (3 czerwca), Częstochowę (4-6 czerwca), Kraków (6 i 8-10 czerwca), Oświęcim (7 czerwca), Kalwarię Zebrzydowską ( 7 czerwca), rodzinne Wadowice ( 7 czerwca) i Nowy Targ ( 8 czerwca) ${ }^{49}$.

W sobotę - 2 czerwca 1979 r. - w dniu przyjazdu papieża Jana Pawła II do Polski około godz. 10.00 tow. Łucja Igielska wysłała do

\footnotetext{
${ }^{47}$ Ibid., 365, teleksy dotyczące wizyty papieża Jana Pawła II w Polsce w czerwcu 1979 r., k. 18, teleks nr 185 wysłany z KC PZPR w dniu 28 maja 1979 r.

${ }^{48}$ Politolog Bogdan Szajkowski opisał te dziewięć dni czerwca jako ,psychologiczny wstrząs, okazję do masowej politycznej katharsis”. Zob. G. Weigel, Ostateczna rewolucja. Kościót sprzeciwu a upadek komunizmu, przeł. W. Buchner, Poznań 1995, s. 182.

${ }^{49}$ Szczegółowe kalendarium: Jan Pawet II, Przemówienia. Homilie, Polska 2.06. 1979 - 10.06.1979, Kraków 1979, s. 5-9; Komunikaty Konferencji Episkopatu Polski 1945-2000, wstęp i oprac. J. Żaryn, Poznań-Warszawa 2006, s. 209-210.
} 
Wydziału Organizacyjnego Komitetu Centralnego PZPR raport dotyczący nastrojów i stanu przygotowania do pielgrzymki:

Nie zanotowaliśmy żadnych negatywnych wydarzeń politycznych. Na uwagę zasługuje fakt, iż wieś nie wystąpiła $\mathrm{z}$ masową dekoracją. $\mathrm{W}$ dniu dzisiejszym w godzinach rannych zaobserwowaliśmy w miastach także nieliczne fakty dekoracji okien i domów mieszkań prywatnych. W samym Toruniu przypadków takich jest około 20 . Większa ilość dekoracji mieszkań prywatnych występuje w miastach Wąbrzeźnie i Chełmży. Nawet nie wszystkie obiekty sakralne w województwie zostały udekorowane, m.in. w Toruniu i w Nowym Mieście Lubawskim.

W dniu dzisiejszym w godzinach popołudniowych o godz. $18.00 \mathrm{z}$ Torunia do Warszawy udaje się około 150-osobowa grupa młodzieży akademickiej pod przewodnictwem 2 księży jezuitów ${ }^{50}$.

W informacji z 4 czerwca 1979 r., a więc sporządzonej już po warszawskim i gnieźnieńskim etapie papieskiej pielgrzymki na temat komentarzy i opinii społeczeństwa województwa toruńskiego napisano:

Według relacji powracających pielgrzymów z Gniezna zgromadziło się tam około 2 milionów wiernych. $Z$ naszego województwa 15 autokarami wyjechało około 700 osób, zaś pociągami około 600 . Z posiadanego rozeznania wynika, że z terenu województwa nie będzie grupowych wyjazdów na uroczystości do Częstochowy ${ }^{51}$.

W informacji Komendy Wojewódzkiej MO w Toruniu przesłanej na ręce I sekretarza Komitetu Wojewódzkiego PZPR w Toruniu 5 czerwca 1979 r. zawarto bardzo interesujące, jeśli nie wręcz sensacyjne wiadomości:

W środowisku inteligencji katolickiej mówi się, że tow. E. Gierek poważnie podbudował swój autorytet doprowadzając do przyjazdu papieża. Komentuje się, iż w Gnieźnie nie doszło do zapowiadanego obiadu i spotkania papieża z zaproszonymi księżmi oraz inteligencją katolicką, ponieważ organizatorzy spodziewali się bliżej nieokreślonej prowokacji (papież celowo przedłużył spotkanie z młodzieżą) $)^{52}$.

\footnotetext{
${ }^{50}$ APT, KW PZPR w Toruniu, Kancelaria I Sekretarza, 365, teleksy dotyczące wizyty papieża Jana Pawła II w Polsce w czerwcu 1979 r., teleks z dnia 2 czerwca 1979 r.

${ }^{51}$ Ibid., 364, teleksy KW - KC marzec - czerwiec 1979 r., k. 169, teleks nr 141/I/79 z 4 czerwca 1979 r.

${ }^{52}$ Ibid., 365, teleksy dotyczące wizyty papieża Jana Pawła II w Polsce w czerwcu 1979 r., informacja KW MO w Toruniu z dnia 5 czerwca 1979 r.
} 
Opisano także nastroje panujące wśród toruńskich studentów:

W kręgach młodzieży akademickiej notujemy opinie, że władze państwowe zezwoliły na odprawienie nabożeństwa na Placu Zwycięstwa w Warszawie, ponieważ doskonale zdaje sobie sprawę, jaką siłę aktualnie przedstawia Kościół w Polsce. Wskazuje się, iż w przemówieniach powitalnych I Sekretarza Komitetu Centralnego PZPR, Przewodniczącego Rady Państwa oraz papieża uwidoczniły się wyraźne rozbieżności co do celu wizyty Jana Pawła II. Władze pragną utożsamić fakt ten z obchodami XXXV-lecia PRL i XL rocznicą wybuchu wojny, natomiast papież swoją wizytę traktuje jako pielgrzymkę z okazji 900. rocznicy śmierci św. Stanisława biskupa ${ }^{53}$.

W notatce z 16 czerwca 1979 r. dokonano podsumowania papieskiej pielgrzymki, zwracając uwagę na komentarze, reakcje i zachowania różnych grup społecznych. Przewrotnie zauważono:

Notowaliśmy również bardzo zróżnicowane komentarze i opinie poszczególnych środowisk. Wszystkie środowiska bardzo wysoko oceniały przemówienia I Sekretarza KC PZPR w Belwederze oraz Przewodniczącego Rady Państwa na obu lotniskach ${ }^{54}$.

Odmiennie natomiast według relacji partyjnych oceniać miano wystąpienia papieża, choć:

Podkreślano również wyważoną treść oficjalnych przemówień papieża. Pozytywnie oceniono przemówienie papieża w Oświęcimiu-Brzezince. Wielokrotnie we wszystkich środowiskach stwierdzano, że Jan Paweł II dał świadectwo dążenia Kościoła do pokoju na świecie i współpracy między narodami.

Wśród kadry naukowej UMK podkreślono, że w kazaniu wygłoszonym w dniu 2 czerwca br. na Placu Zwycięstwa w Warszawie papież wyłożył swoje credo i zaprezentował linię polityki Kościoła wobec państw socjalistycznych.

Wskazywano na kurs obecnej polityki Watykanu, oparty na zasadzie niezmiennej, bezwzględnej dominacji ruchu społeczno-politycznego $\mathrm{w}$ łonie Kościoła, opartego na dążeniu do uniwersalnego przywództwa ${ }^{55}$.

Dziś może zaskakiwać podsumowanie, jakim kończy się cytowana notatka. Jednak w rzeczywistości PRL wszystkie osiągnięcia i sukcesy były mniej lub bardziej zasługą partii:

\footnotetext{
${ }^{53}$ Ibid.

${ }^{54}$ Ibid., notatka sporządzona w dniu 16 czerwca 1979 r. z przebiegu działań w okresie przed i w czasie pobytu papieża w Polsce oraz komentarze i opinie środowisk społeczno-zawodowych województwa toruńskiego.

${ }^{55}$ Ibid.
} 
Reasumując należy stwierdzić, że tak w okresie poprzedzającym wizytę papieża, jak i czasie jej trwania na terenie województwa toruńskiego nie zanotowano negatywnych wydarzeń, społeczno-politycznych napięć, jak również sytuacji konfliktowych.

Klimat ten zawdzięczamy głównie właściwie zaprogramowanej pracy ideowo-wychowawczej i politycznej, systematycznie prowadzonej przez instancję wojewódzką i terenowe ${ }^{56}$.

Papieskie pielgrzymowanie w czerwcu 1979 r. stało się zaczynem, z którego w sierpniu 1980 r. narodziła się NSZZ „Solidarność”. Jednak wtedy, w czerwcu 1979 r., władze państwowe i partyjne nie zdawały sobie sprawy z epokowych konsekwencji wizyty Biskupa Rzymu. Większość powstałych wówczas analiz i prognoz cechował przesadny optymizm, zwracano m.in. uwagę, iż przebiegiem pielgrzymki rozczarowane były środowiska opozycyjne, a frekwencja wiernych była niższa niż oczekiwała strona kościelna ${ }^{57}$. Tylko ocena wizyty sporządzona przez Jana Szczepańskiego ${ }^{58}$ zawierała prognozę powstania masowego ruchu społecznego 59 .

Oceniając przedstawione w materiałach Komitetu Wojewódzkiego PZPR w Toruniu reakcje i zachowania społeczne podkreślić należy, że w bardzo niewielkim stopniu ukazano samodzielne działania środowisk katolickich. Nie zawierają one nawet śladowych danych na temat indywidualnych bądź nieformalnych - grupowych wyjazdów na szlak papieskiej podróży po Polsce. Dobrym przykładem może być środowisko Klubu Inteligencji Katolickiej w Toruniu. Na spotkanie z papieżem w Warszawie (2 czerwca 1979 r.) udali się: Zofia i Andrzej Tycowie. Do Gniezna - Gębarzewa (3 czerwca 1979 r.) wyjechali m.in.: Zofia Buske, Beata Chomicz, Ewa i Roman Gąsiorowscy, Ryszard Konikiewicz z synami, Maria i Bogdan Majorowie, wspomniani już Barbara

\footnotetext{
${ }^{56}$ Ibid

${ }^{57}$ Ł. Kamiński, PZPR wobec pielgrzymki Jana Pawła II do Ojczyzny w 1979 roku, Biuletyn IPN, nr 7(2002), s. 39-42.

${ }^{58}$ Jan Szczepański (ur. 14 września 1913 r., zm. 16 kwietnia 2004 r.). Wybitny socjolog. Od 1951 r. profesor Uniwersytetu Łódzkiego. W latach 1952-1956 rektor Uniwersytetu Łódzkiego. Od 1966 do 1970 r. przewodniczący Międzynarodowego Stowarzyszenia Socjologicznego. Od 1970 r. członek rzeczywisty PAN. W latach 1977-1982 członek Rady Państwa PRL (bezpartyjny).

${ }^{59}$ Wizyta Jana Pawta II w Polsce 1979. Dokumenty KC PZPR i MSW, s. 322-325.
} 
i Jerzy Matyjkowie, Krystyna Porębska, Barbara Rojek, Zofia i Andrzej Tycowie $^{60}$. Natomiast w Nowym Targu (8 czerwca 1979 r.) z Ojcem św. spotkali się Maryla i Jan Adamiakowie. Do Krakowa dotarł Jerzy Matyjek, który - wraz z Andrzejem Tycem - został przyjęty przez papieża podczas audiencji dla przedstawicieli ruchu „ZNAK” zorganizowanej w pałacu arcybiskupów krakowskich (8 czerwca 1979 r. $)^{61}$.

Dobór przekazywanych do Komitetu Centralnego PZPR relacji wskazuje, iż podlegały one wewnętrznej cenzurze partyjnej. Prezentowane odgłosy reakcji rozmaitych środowisk najczęściej wyrażane są przy użyciu ,języka aparatu partyjnego" ${ }^{2}$. W wielu rzekomych wypowiedziach pochodzących z kręgów aktywu partyjnego dominuje ton, z którego można odczytać krytyczną ocenę Kościoła katolickiego. Natomiast $\mathrm{w}$ innych anonimowych wypowiedziach przypisuje się samemu papieżowi lub hierarchii wygodne dla władz komunistycznych postawy. Przykładem takich zabiegów jest interpretacja wystąpienia Jana Pawła II w obozie zagłady w Oświęcimiu przekazana w teleksie z 8 czerwca 1979 r.:

Z zainteresowaniem i uwagą oglądano natomiast wczorajsze uroczystości w Oświęcimiu. Stwierdza się, że miały one poważny i doniosły charakter, a wystąpienie papieża określa się jako patriotyczne, potępiające zbrodnie hitlerowskie.

Podkreśla się przede wszystkim, że Jan Paweł II wspominając o narodach najbardziej poszkodowanych w okresie II wojny światowej wymienił Rosjan, którzy nieśli wolność innym narodom. Przyjęto to jako podkreślenie udziału Związku Radzieckiego w wyzwoleniu naszego kraju oraz w usilnych działaniach na rzecz pokoju ${ }^{63}$.

\footnotetext{
${ }^{60}$ M. Białkowski, Wiara i nauka - siostry wolności. Zarys działalności religijnej, politycznej i naukowej Profesora Andrzeja Tyca, [w:] Ludzie wolności w regionie kujawsko-pomorskim, red. M. Białkowski, Z. Biegański, W. Polak, t. IV serii: Dzieje Regionu Kujawsko-Pomorskiego, Toruń 2014, s. 197.

${ }^{61}$ M. Białkowski, Oaza na Mostowej. Klub Inteligencji Katolickiej w Toruniu (1957-2007), s. 140-141; idem, Jerzy Matyjek (1926-2017) - szkic do portretu, Rocznik Toruński, t. 44, 2017, s. 220.

${ }^{62}$ Ciekawe uwagi na ten temat zawiera publikacja: J. Bralczyk, O języku polskiej propagandy politycznej lat siedemdziesiatych, Warszawa 2001.

${ }^{63}$ APT, KW PZPR w Toruniu, Kancelaria I Sekretarza, 365, teleksy dotyczące wizyty papieża Jana Pawła II w Polsce w czerwcu 1979 r., teleks z dnia 8 czerwca 1979 r.
} 
Bezpośrednio po niej odniesiono się natomiast do warunków pogodowych oraz sytuacji w rolnictwie:

Z uznaniem wysoko oceniamy wysiłek ludzi pracy województwa szczególnie w obecnym okresie upałów.

[...] W rolnictwie prace koncentrują się głównie na wykonywaniu czynności przy zbiorach traw i zielonek oraz pracach pielęgnacyjnych w uprawach roślin. Przerywkę buraków wykonano na powierzchni 19600 ha, tj. 88\% w stosunku do powierzchni zasianej ${ }^{64}$.

Natomiast wręcz absurdalnie i groteskowo brzmią ostatnie akapity tej notatki:

W miastach i gminach województwa rozpoczęły się przygotowania do obchodów Święta Odrodzenia 22 Lipca. Powoluje się obywatelskie komitety obchodów święta oraz przyjmuje do realizacji lokalne programy obchodów.

Wojewódzka instancja partyjna przygotowuje się do plenarnego posiedzenia KW nt. „Zadań i kierunków rozwoju przemysłu rolno-spożywczego woj. toruńskiego do 1985 r." ${ }^{, 65}$.

$$
* * *
$$

Obraz mieszkańców Torunia i województwa toruńskiego utrwalony w materiałach Komitetu Wojewódzkiego PZPR podlegał propagandowemu zniekształceniu, przejaskrawieniu i zafałszowaniu. Będąc oryginalnym wytworem partyjnej machiny biurokratycznej ukazywał życie obywateli PRL-u w sposób karykaturalny, charakterystyczny dla postrzegania otaczającego świata przez aparatczyków ${ }^{66}$. Przedstawiona rzeczywistość - mocno podkoloryzowana - wydaje się wielkim złudzeniem, w którym społeczeństwo powszechnie wyraża swoją aprobatę, uznanie i zainteresowanie dla działań partii i najwyższych władz państwowych, brakuje natomiast żywiołowo wyrażanych szczerych uczuć wobec Pasterza Kościoła Powszechnego. Oprócz takiego obrazu zauważalne są działania władz partyjno-państwowych mające na celu ograniczenie udziału wiernych w spotkaniach z papieżem. Peryferyjni aparatczycy wysyłali więc do centrali wyraźny przekaz o przeciwdzia-

\footnotetext{
${ }^{64}$ Ibid.

${ }^{65}$ Ibid.

${ }^{66}$ Zob. L. Tyrmand, Cywilizacja komunizmu, Łomianki 2006.
} 
łaniu praktykom religijnym oraz skanalizowaniu entuzjastycznych nastrojów społecznych.

\section{Bibliografia}

Źródła archiwalne

Archiwum Państwowe w Toruniu (APT), Zespół Komitetu Wojewódzkiego PZPR w Toruniu (KW PZPR w Toruniu), sygn. 48; 58; Listy płac.

APT, KW PZPR w Toruniu, Kancelaria I Sekretarza, sygn. 362, teleksy dotyczące pontyfikatu papieża Jana Pawła II

APT, KW PZPR w Toruniu, Kancelaria I Sekretarza, sygn. 363, teleksy KW KC styczeń - marzec 1979 r.

APT, KW PZPR w Toruniu, Kancelaria I Sekretarza, sygn. 364, teleksy KW KC marzec - czerwiec $1979 \mathrm{r}$.

APT, KW PZPR w Toruniu, Kancelaria I Sekretarza, sygn. 365, teleksy dotyczące wizyty papieża Jana Pawła II w Polsce w czerwcu 1979 r.

Źródła drukowane

Centrum władzy. Protokoly posiedzeń kierownictwa PZPR wybór z lat 19491970, oprac. A. Dudek, A. Kochański, K. Persak, Warszawa 2000.

Jan Pawet II, Przemówienia. Homilie, Polska 2.06.1979 - 10.06.1979, Kraków 1979.

Komunikaty Konferencji Episkopatu Polski 1945-2000, wstęp i oprac. J. Żaryn, Poznań-Warszawa 2006.

Metody pracy operacyjnej aparatu bezpieczeństwa wobec Kościolów i zwiazków wyznaniowych 1945-1989. Dokumenty, wstęp, wybór dokumentów, redakcja A. Dziurok, Warszawa 2004.

Polska Ludowa. Modzelewski, Werblan. Rozmawia Robert Walenciak, Warszawa 2017.

Raina P., Kościót katolicki a państwo w świetle dokumentów 1945-1989, t. 1: Lata 1945-1959, Poznań 1994; t. 2: Lata 1960-1974, Poznań 1995; t. 3: Lata 1975-1989, Poznań 1996.

Rakowski M. F., Dzienniki polityczne 1976-1978, t. 6, Warszawa 2002.

Wizyta Jana Pawta II w Polsce 1979. Dokumenty KC i MSW, wstęp i oprac. A. Friszke i M. Zaremba, Warszawa 2005.

Opracowania

Bäcker R., Struktury poziome w Toruniu 1980-1981, Warszawa 1990. 
Białkowski M., Jerzy Matyjek (1926-2017) - szkic do portretu, Rocznik Toruński, t. 44, 2017, s. 203-232.

Białkowski M., Oaza na Mostowej. Klub Inteligencji Katolickiej w Toruniu (1957-2007), Toruń 2008.

Białkowski M., Wiara i nauka - siostry wolności. Zarys działalności religijnej, politycznej i naukowej Profesora Andrzeja Tyca, [w:] Ludzie wolności $w$ regionie kujawsko-pomorskim, red. M. Białkowski, Z. Biegański, W. Polak, t. IV serii: Dzieje Regionu Kujawsko-Pomorskiego, Toruń 2014 , s. 187-207.

Białkowski M., Wokół Soboru Watykańskiego II. Studia i szkice, Toruń 2016.

Biuletyn Informacyjny PZPR. Komitet Wojewódzki w Toruniu, nr 1/17: 1979.

Biuletyn Informacyjny PZPR. Komitet Wojewódzki w Toruniu, nr 18/1981.

Boboli A., ,,Przewodnia siła stolicy”. Komitet Warszawski Polskiej Zjednoczonej Partii Robotniczej 1975-1990, Warszawa 2016.

Bralczyk J., O języku polskiej propagandy politycznej lat siedemdziesiatych, Warszawa 2001.

Cichocki B., Jóźwiak K., Najważniejsze sa kadry. Centralna Szkoła Partyjna PPR/PZPR, wstępem opatrzyli M. Kula i R. Turkowski, Warszawa 2006.

Członkowie władz naczelnych oraz I sekretarze Komitetów Wojewódzkich PZPR 21.12.1948 - 31.12.1982, oprac. W. Ciempiel, J. Jakubowski, J. Szczeblewski, Warszawa 1983.

Dąbek K., PZPR. Retrospektywny portret własny, Warszawa 2006.

Dudek A., PRL bez makijażu, Kraków 2008.

Dudek A., Gryz R., Komuniści i Kościół w Polsce (1945-1989), Kraków 2003.

Dziurok A., Kruchtoizacja. Polityka władz partyjno-państwowych wobec Kościoła katolickiego $w$ latach 1945-1956 w województwie śląskim/katowickim, Katowice 2012.

Dziwisz S., Svidercoschi G. F., Świadectwo, Poznań 2007.

Elity komunistyczne $w$ Polsce, red. M. Szumiło i M. Żukowski, WarszawaLublin 2015.

Fijałkowska B., Partia wobec religii i Kościoła w PRL, t. 1: 1945-1955, Olsztyn 1999; t. 2, cz. 1: 1956-1963, cz. 2: 1964-1970, Olsztyn 2000-2001.

Góra W., Polska Ludowa 1944-1984. Zarys dziejów politycznych, Lublin 1986.

Informator Wojewódzkiej Organizacji Partyjnej PZPR. Komitet Wojewódzki $w$ Toruniu, nr 40/81.

Karpiński J., Ustrój komunistyczny w Polsce, Warszawa 2005.

Komitet Wojewódzki ogniwem władzy ludowej. Studium postaw aktywu partyjnego, oprac. pod kierunkiem M. Kuli na przykładzie zapisów posiedzeń KW PZPR w Gdańsku w latach 1949-1953, Warszawa 1997. 
Kościót i Prymas Stefan Wyszyński 1956-1966, red. A. Dziurok i W. J. Wysocki, Katowice-Kraków 2007.

Łatka R., Polityka władz PRL wobec kościoła katolickiego $w$ województwie krakowskim w latach 1980-1989, Kraków 2016.

Moskwa J., Jan Pawet II. Autorytety, Warszawa 2005.

Najnowsza historia Kościoła. Katolicy i Kościoły chrześcijańskie w czasie pontyfikatu Jana Pawła II (1978-2005), red. E. Guerriero, M. Impagliazzo, przeł. J. Partyka, Kraków 2008.

Nitecki P., Biskupi Kościoła w Polsce w latach 965-1999. Stownik biograficzny, Warszawa 2000.

Noszczak B., Polityka państwa wobec Kościoła rzymskokatolickiego w Polsce $w$ okresie internowania prymasa Stefana Wyszyńskiego 1953-1956, Warszawa 2008.

Paczkowski A., System nomenklatury, [w:] Centrum władzy w Polsce 19481970, red. A. Paczkowski, s. 115-139.

Partia, państwo, społeczeństwo, red. K. Rokicki, Warszawa 2016.

Persak K., Struktura i skład centralnych instancji decyzyjnych KC PZPR, [w:] Centrum wladzy $w$ Polsce 1948-1970, red A. Paczkowski, Warszawa 2003, s. 19-50.

PRL na pochylni (1975-1980), red. M. Bukała, D. Iwaneczko, Rzeszów 2017.

Prokop K. R., Biskupi Kościoła katolickiego w III Rzeczpospolitej. Leksykon biograficzny, Kraków 1998.

PZPR jako machina władzy, red. D. Stola i K. Persak, Warszawa 2012.

PZPR w fabryce. Studium wrocławskiego „Pafawagu” w początku lat pięćdziesiatych, oprac. pod kierunkiem M. Kuli, Warszawa 2001.

Riccardi A., Jan Pawet II. Biografia, tłum. K. Stopa, Częstochowa 2014.

Skrzypczak R., Karol Wojtyła na Soborze Watykańskim II. Zbiór wystapień, Warszawa 2011.

Spałek R., Komuniści przeciwko komunistom. Poszukiwanie wroga wewnętrznego w kierownictwie partii komunistycznej w Polsce w latach 1948-1956, Warszawa-Poznań 2014.

Staniszkis J., Ontologia socjalizmu, Kraków-Nowy Sącz 2006.

Szulc T., Papiez Jan Pawet II. Biografia, przeł. Z. Uhrynowska-Hanasz, M. Wroczyński, Warszawa 1999.

Tyrmand L., Cywilizacja komunizmu, Łomianki 2006.

Weigel G., Ostateczna rewolucja. Kościół sprzeciwu a upadek komunizmu, przeł. W. Buchner, Poznań 1995.

Władza w PRL. Ludzie i mechanizmy, red. K. Rokicki, R. Spałek, Warszawa 2011. 
Wojtyła K., U podstaw odnowy. Studium o realizacji Vaticanum II, wyd. 1, Kraków 1972.

Zuchniewicz P., Jan Pawet II. „Będę szedt naprzód”, Kraków 2009.

Żaryn J., Dzieje Kościoła katolickiego w Polsce (1944-1989), Warszawa 2003.

Artykuły

Kamiński Ł., Przewodnia siła narodu, Biuletyn IPN, nr 5(2002).

Kamiński Ł., PZPR wobec pielgrzymki Jana Pawła II do Ojczyzny w 1979 roku, Biuletyn IPN, nr 7(2002).

Kierunki rozwoju województwa tematem narady aktywu partyjno-gospodarczego, Nowości z dnia 9 czerwca 1975 r.

Skibiński P., Pielgrzymki Jana Pawła II do Ojczyzny (1979-2002) i ich kontekst historyczny, Teologia Polityczna, 3/2005-2006.

Wojtyła K., Udziat biskupów polskich w Soborze Watykańskim II, Wiadomości Archidiecezjalne Warszawskie, 61(1971), nr 5.

Streszczenie: Wybór Jana Pawła II (16 października 1978 r.), inauguracja Jego pontyfikatu (22 października 1978 r.) oraz I Pielgrzymka do Ojczyzny (2-10 czerwca 1979 r.) były wydarzeniami bez precedensu, stąd zainteresowanie nimi przejawiały centralne organa partyjno-państwowe PRL. Początkowo wywołały one szok wśród najwyższych decydentów partyjnych, później dość szybko skłoniły do przeprowadzenia szerokich analiz. Zaprezentowane materiały - pochodzące z Archiwum Państwowego w Toruniu, zespół Komitetu Wojewódzkiego PZPR w Toruniu - są przykładem takich dokumentów sporządzonych przez aparat partyjny średniego szczebla. Codziennie przygotowywane - przez Kancelarię I Sekretarza Komitetu Wojewódzkiego PZPR w Toruniu - raporty charakteryzuje specyficzny język nowomowy partyjnej, brak autorefleksji oraz znikomy obiektywizm ocenianej rzeczywistości, oceny oparte na stereotypach, tendencje zaniżające wartości bądź wielkości (m.in. reakcji społecznych, jakie wywołał wybór kardynała Karola Wojtyły na Stolicę Piotrową, liczby świeckich uczestniczących w spotkaniach z Papieżem). Z perspektywy czterech dekad partyjne sprawozdania pozostają świadectwem propagandowego karykaturalnego zniekształcenia obrazów z życia codziennego Kościoła oraz mieszkańców województwa toruńskiego. 


\title{
The beginning of the pontificate and the $1^{\text {st }}$ Pilgrimage of Pope John Paul II to Poland in the light of the sources of the Provincial Committee of the Polish United Workers' Party in Torun
}

\begin{abstract}
The election of John Paul II ( on 16 October 1978), the inauguration of his pontificate (22 October 1978) and the $1^{\text {st }}$ Pilgrimage to Poland (210 June 1979) were unprecedented events, which is why various central political bodies of the Polish People's Republic were interested in them. Originally, they provoked shock among the highest dignitaries of the party, but later they made them carry out extensive analyses. The materials presented here - from the State Archive in Torun, the complex of the Provincial Committee of the Polish United Workers' Party (PZPR) in Torun - constitute an example of such documents prepared by the middle-level party apparatus. Reports - prepared daily by the Bureau of the $1^{\text {st }}$ Secretary of the Provincial Committee of PZPR in Torun - are characterized by a specific language of the party's newspeak, a lack of self-reflection and scarce objectivity in the evaluation of the reality evaluation based on stereotypes, tendencies to underestimate the value or importance (e.g. of social reactions generated by the choice of Cardinal Karol Wojtyła to be the pope, the number of laymen participating in the meetings with the Pope). From the perspective of four decades the party's reports remain the evidence of the propagandist distortion of the images of everyday life of the Church and inhabitants of the Kuyavian-Pomeranian Province.
\end{abstract}

\section{Der Beginn des Pontifikats und die erste Pilgerreise von Johannes Paul II. nach Polen im Licht der Archivalien des Wojewodschaftskomitees der PVAP in Thorn}

Zusammenfassung: Die Wahl von Johannes Paul II. zum Papst (16. Oktober 1978), seine Amtseinführung (22. Oktober 1978) und die erste Pilgerfahrt in sein Vaterland (2.-10. Juni 1979) waren Ereignisse ohne Beispiel, weshalb die zentralen Organe von Partei und Staat der Volksrepublik Polen großes Interesse für sie an den Tag legten. Zunächst hatten sie bei den höchsten Entscheidungsträgern der Partei einen Schock hervorgerufen, danach führten sie relativ schnell zur Durchführung breit angelegter Analysen. Die hier vorgestellten Materialien stammen aus den Beständen des Wojewodschaftskomitees der Polnischen Vereinigten Arbeiterpartei (PVAP) in Thorn, die sich im Thorner Staatsarchiv befinden, und sind ein Beispiel für Dokumente, die von der mit- 
tleren Ebene des Parteiapparats angefertigt wurden. Die Berichte wurden täglich von der Kanzlei des Ersten Sekretärs des Wojewodschaftskomitees der PVAP in Thorn angefertigt und sind gekennzeichnet durch ein spezifisches Partei-Neusprech, durch einen Mangel an Selbstreflexion, eine minimale Objektivität gegenüber der beurteilten Wirklichkeit, durch auf Stereotypen gestützte Urteile und durch eine Neigung, Werte oder Größen herabzusetzen (u. a. die Reaktionen, die die Wahl von Kardinal Wojtyła auf den Stuhl Petri in der Bevölkerung hervorrief, die Menge der Gläubigen, die an den Begegnungen mit dem Papst teilnahmen). Im Rückblick nach vier Jahrzehnten sind die Parteiberichte ein Zeugnis einer karikaturhaften Verzeichnung von Bildern aus dem Alltagsleben der Kirche und der Bewohner der Wojewodschaft Thorn zu Propagandazwecken.

Słowa kluczowe: PZPR, Komitet Wojewódzki PZPR w Toruniu, Jan Paweł II, inauguracja pontyfikatu, I Pielgrzymka do Ojczyzny, diecezja chełmińska

Keywords: the Polish United Workers' Party (PZPR), the Provincial Committee of the Polish United Workers' Party (PZPR) in Torun, John Paul II, inauguration of the pontificate, the $1^{\text {st }}$ Pilgrimage to Poland, Chełmno diocese

Schlüsselwörter: PVAP, Wojewodschaftskomitee der PVAP in Thorn, Johannes Paul II., Amtseinführung als Papst, erste Reise nach Polen, Bistum Kulm 